THE UNECIC: INTERNATIONAL TRADE IN THE DIGITAL ERA

\title{
S Eiselen
}

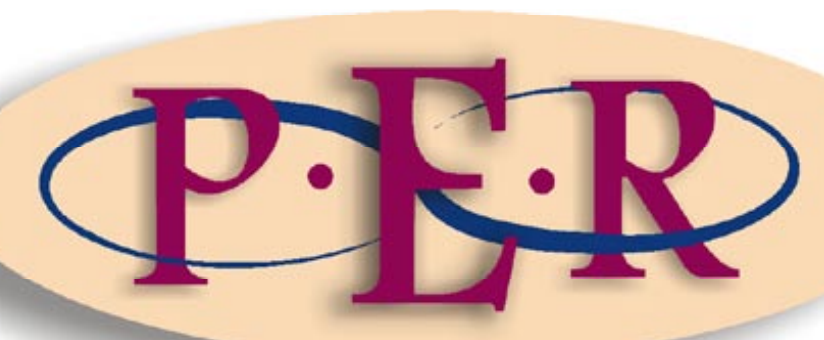

2007 Volume 2 


\section{THE UNECIC: INTERNATIONAL TRADE IN THE DIGITAL ERA}

S Eiselen*

\section{Introduction}

The use of electronic means of communication such as e-mail, SMS and the internet in the last decade has outstripped and replaced other more traditional forms of communications such as post, telex and telegram. The only other form of communication which has been able to hold its own, is fax, which in any event is of fairly recent origin and is increasingly becoming integrated into the other forms of electronic communications. The convergence of technologies is also increasingly diffusing the boundaries between these various forms of electronic communications. Most cell phones, for instance have become a small computer enabling the user to use either voice, SMS, e-mail and even fax from the same instrument, as well as accessing the internet.

The internet has had the added effect that all forms of communications (including voice) have become much faster, cheaper and, importantly, international. Distance in the digital world has virtually no meaning and has almost erased the importance of national boundaries in communications. ${ }^{1}$ These developments have also changed the face of communications in international trade. The ease and reliability of communications have facilitated the development of international trade as traders can advertise and sell their wares independent of where buyer and seller may find themselves in the world. $^{2}$ This is also important for developing nations as it opens up international markets to smaller traders from developing nations to an unprecedented extent.

* $\quad$ B Juris, LL B, LL D; Professor in Private Law, University of South Africa; member of the Johannesburg Bar.

1 Reed and Angel (eds) Computer Law Ixii-Ixiii; 197.

2 Cheeseman Business and Online Commerce Law 299-300; Reed and Angel (eds) Computer Law Ixii-Ixiii. 
It is a common perception that the law, and more particularly the law of contract, has been lagging behind in the development of solutions for the use of electronic communications in commerce, leading to legal uncertainty which in turn creates obstacles to trade. ${ }^{3}$ This perception exists not only in respect of international law, but also in respect of most domestic legal systems. ${ }^{4}$ Some of the questions usually raised include: the legal value and validity of electronic communications; compliance with formalities; whether electronic signatures are possible and valid; determining the time and place of the conclusion of the contract; the validity of automated transactions; the applicable legal system; the evidential value of electronic records; and similar issues. ${ }^{5}$

The fact that many of these issues could already be adequately accommodated in terms of existing flexible rules, ${ }^{6}$ has not removed these perceptions about legal uncertainty. It provided the ground for UNCITRAL to develop a Model Law on Electronic Commerce (1996) ${ }^{7}$ and a Model Law on Electronic Signatures $(2001)^{8}$ and finally the United Nations Convention on the Use of Electronic Communications in International Contracts, 2005 (UNECIC). The two model laws were aimed at standardising and facilitating the response of domestic legal systems to the challenges of electronic commerce and have subsequently been used in the drafting of the domestic legislation of a fairly large number of countries, including South Africa. ${ }^{9}$ The UNECIC, in turn, aims at establishing

3 Par 4 Working Group Report 5-9 May 2003 A/CN.9/528 (19 May 2003); UNCITRAL 1996 Guide to Enactment with a 5 bis as adopted in 1998 par 2 and 3. See also the DoC 2000 Green Paper on eCommerce http://www.polity.org.za/ 19 Nov.

4 UNCITRAL 1996 Guide to Enactment par 2.

5 See UNCITRAL "Legal barriers to the development of electronic commerce in international instruments relating to international trade Compilation of comments by Governments and international organizations" A/CN.9/WG.IV/WP.94 (14 February 2002); DoC 2000 Green Paper on eCommerce http://www.polity.org.za/ 19 Nov.

6 Par 30 and 31 Working Group Report 5-9 May 2003 A/CN.9/528 (19 May 2003).

7 Adopted by UNCITRAL on 12 June 1996. See G.A.Res.51/162, adopted on 16 December 1996, UN Doc.A/RES/51/162 (30 January 1997). The Model Law provided the basis for ch 3 of the South African Electronic Communications and Transactions Act 25 of 2002 (UNCITRAL 1996 Guide to Enactment).

8 Adopted by UNCITRAL on 5 July 2001. See G.A.Res56/80 adopted on 12 December 2001, UN Doc.A/RES/56/80 (24 June 2002).

9 Legislation implementing provisions of the Model Law has been adopted in: Australia (1999), China (2004), Colombia (1999), Dominican Republic (2002), Ecuador (2002), France (2000), India (2000), Ireland (2000), Jordan (2001), Mauritius (2000), Mexico (2000), New Zealand (2002), Pakistan (2002), Panama (2001), Philippines (2000), Republic of Korea (1999), Singapore (1998), Slovenia (2000), South Africa (2002), Sri 
legal certainty in international trade by providing solutions and harmonising rules on electronic communications for international transactions. ${ }^{10}$

The United Nations General Assembly on 23 November 2005 adopted the UNECIC as a new convention on the use of electronic communications in international contracts. The UNECIC has, however, not yet come into operation. ${ }^{11}$ The stated object of the Convention is to -

...provide a common solution to remove legal obstacles to the use of electronic communications in a manner acceptable to States with different legal, social and economic systems.

The scope and field of application of the UNECIC is closely aligned to that of the Vienna Convention for the International Sale of Goods, 1980 (CISG), although the UNECIC potentially has a wider field of application than pure sales.

To date very little analysis of the UNECIC has been undertaken. ${ }^{12}$ In this contribution the following aspects will be discussed in an attempt to highlight the importance of the convention as an instrument for international legal harmonisation in the field of international trade and trade communications:

(a) the legislative history of the UNECIC;

(b) its scope and purpose and the underlying principles on which it is based as a background or basis for its interpretation;

Lanka (2006), Thailand (2002), Venezuela (2001) and Vietnam (2005). Uniform legislation influenced by the Model Law and the principles on which it is based has been prepared in the United States (Uniform Electronic Transactions Act, adopted in 1999 by the National Conference of Commissioners on Uniform State Law) and enacted in 49 of its states, and in Canada (Uniform Electronic Commerce Act, adopted in 1999 by the Uniform Law Conference of Canada) and enacted in 11 of its provinces and territories.

10 See the UNECIC Preamble.

11 In terms of a 23 the UNECIC only enters into force upon the deposit of the third instrument of ratification, acceptance, approval or accession. By October 2007 none of the 15 signatories had as yet deposited such an instrument, although informally certain countries have already indicated to the UNCITRAL Secretariat that they may do so in the near future.

12 See eg Raymond 2006 The Computer \& Internet Lawyer 9; Connolly 2006 Computer Law \& Security Report 32. 
(c) interpretation of the UNECIC;

(d) Analysis of the provisions of the UNECIC.

\section{Legislative history}

The Working Group on Electronic Commerce within UNCITRAL, which was responsible for the development of the Model Law on Electronic Commerce (1996) and the Model Law on Electronic Signatures, started work on this Convention as a result of a United Nations Centre for Trade Facilitation and Electronic Business (UN/CEFACT) report in 2001. At that time it was of course not yet certain what form the eventual instrument would take on, that is, a model law, a convention, a recommendation or the amendment of existing treaties. The Working Group made a number of recommendations, including -

...the preparation of an international instrument dealing with selected issues on electronic contracting and a comprehensive survey of possible legal barriers to the development of electronic commerce in international instruments. ${ }^{13}$

From the outset one of the main aims of the work to be undertaken was to ensure that legal barriers created by existing international trade instruments be removed. ${ }^{14}$ These recommendations by the Working Group were accepted by UNCITRAL. ${ }^{15}$

It was generally accepted that although the two model laws facilitated electronic commerce on the domestic front, those instruments could not solve the various problems of electronic trading in the international context. ${ }^{16}$ The Working Group considered various proposals at its thirty-eighth session, ${ }^{17}$ including a possible convention to remove obstacles to electronic commerce in existing international

13 Report of the Working Group on Electronic Commerce on the work of its $44^{\text {th }}$ session (Vienna, 11-22 October 2004) A/CN.9/571 par 1.

14 Report of the Working Group on Electronic Commerce on the Work of its $38^{\text {th }}$ Session (New York 12-23 March 2001) A/CN.9/484 (24 April 2001).

15 At its $34^{\text {th }}$ Session (Vienna, 25 June-13 July 2001).

16 Raymond 2006 The Computer \& Internet Lawyer 9.

17 New York, 12-23 March 2001. 
conventions; $^{18}$ dematerialisation of documents of title; ${ }^{19}$ and electronic contracting. ${ }^{20}$ UNCITRAL, in reaction to these proposals, gave the Working Group a broad mandate to deal with issues of electronic contracting. It was, however, decided from the beginning that the Working Group would not deal with consumer contracts but focus on the needs of commercial transactions. ${ }^{21}$

The work soon proceeded on the assumption that the eventual instrument could take on the form of a stand-alone convention dealing with contract formation and electronic commerce. It was further assumed that such a convention should not interfere with the well established regime of the CISG or with the law of contract formation in general. ${ }^{22}$ Even at this early stage the principle of functional equivalence, namely that there should in principle be as little difference as possible between agreements concluded by traditional means and electronic agreements, was stressed. ${ }^{23}$

The Working Group started work on a draft convention at its $39^{\text {th }}$ session in New York in 2002. The eventual draft convention was developed over a number of sessions and years, culminating in the text that was included in the Report of their $44^{\text {th }}$ Session in New York in October 2004. ${ }^{24}$ This draft was considered by UNCITRAL at its $38^{\text {th }}$ Session on 4-15 July 2004 in New York and accepted with a number of smaller amendments and deletions. ${ }^{25}$

18 A/CN.9/WG.IV/WP.89.

19 A/CN.9/WG.IV/WP.90.

20 A/CN.9/WG.IV/WP.91.

21 A/CN.9/WG.IV/WP.109 par 11.

22 It is widely recognised that the CISG is well established as a convention in that it has been accepted as law by 70 countries representing more than three quarters of world trade today. That figure will increase with the expected ratification of the convention by Japan in the near future. Very few major trading nations remain outside the CISG regime today. See Schlechtriem and Schwenzer (eds) Commentary 1; Magnus Von Staudingers Kommentar Einleitung par 1-4.

23 A/CN.9/WG.IV/WP.109 par 11.

24 For a more detailed outline of the process, see the UNCITRAL 2004 Agenda of the Working Group for the $44^{\text {th }}$ Session.

25 For a detailed discussion of the amendments and deletions see Report of the United Nations Commission on International Trade Law on the work of its $38^{\text {th }}$ session (4-15 July 2005) A/60/17 p 4-40. 
UNCITRAL thereupon recommended the acceptance of the draft convention to the General Assembly of the United Nations. ${ }^{26}$

The travaux préparatoires of the UNECIC consist of the agendas, reports and working documents of the Working Group within UNCITRAL, such documents of UNCITRAL itself and finally the Secretariat Commentary on the UNECIC. This documentation, which is an invaluable interpretational aid to the Convention, is conveniently collected on and available at the UNCITRAL website. $^{27}$

The General Assembly at its $53^{\text {rd }}$ Plenary Meeting on 23 November 2005 adopted the UNECIC. Although 10 states have to date signed the Convention, ${ }^{28}$ no instrument of ratification, approval, accession or acceptance has as yet been deposited with the Secretary-General as required in article 23. The Convention will only come into operation six months after the deposit of such instruments by at least three countries. ${ }^{29}$

\section{Purpose, scope and field of application}

\subsection{Introduction}

UNCITRAL was founded as a commission with the express object of developing instruments of legal harmonisation in the field of international trade law. ${ }^{30}$ Its first project has also been its most successful, namely the drafting and implementation of the CISG which has been accepted and ratified by 70 nations representing more than two thirds of world trade. ${ }^{31}$ Its success is also

26 At its $810^{\text {th }}$ meeting, on 15 July 2005 - see Report of the United Nations Commission on International Trade Law on the work of its $38^{\text {th }}$ session (4-15 July 2005) A/60/17 p 40-41.

27 UNCITRAL Documentation http://www.uncitral.org/ 8 Aug.

28 Central African Republic, China, Lebanon, Madagascar, Paraguay, Russian Federation, Senegal, Sierra Leone, Singapore and Sri Lanka.

29 A 23(1).

30 See the Prologue to the UNECIC.

31 It is generally recognised that the CISG is one of the most successful legal harmonisation projects ever undertaken. The convention has been adopted and implemented in 70 states from all over the world, including major trading nations, socialist nations, developing nations and even under developed nations, representing more than three quarters of 
reflected in the growing number of case law reflecting a largely uniform approach to the interpretation and application of the convention. ${ }^{32}$ The drafting of the UNECIC is a further step in the harmonisation of international trade law. In this section the stated objects and field of application of the UNECIC will be traversed.

\subsection{Purpose of the UNECIC}

The general purpose of the UNECIC is to provide uniform practical solutions for legal issues emanating from the use of electronic methods of communication in international contracts. ${ }^{33}$ This falls within the wider scope of UNCITRAL's mandate to further the progressive harmonisation and unification of international trade law. ${ }^{34}$ In its Preamble to the adoption of the Convention, the General Assembly recognises that -

...uncertainties as to the legal value of electronic communications exchanged in the context of international contracts constitute an obstacle to international trade,

and that -

...the adoption of uniform rules to remove obstacles to the use of electronic communications in international contracts, including obstacles that might result from the operation of existing international trade law instruments, would enhance legal certainty and commercial predictability for international contracts.

From the outset UNCITRAL worked on the assumption that there existed perceptions that the use of electronic communications in domestic and international law creates legal uncertainty, which in turn creates obstacles in international trade. ${ }^{35}$ The UNECIC was therefore primarily conceived as an

international trade. See Schlechtriem and Schwenzer (eds) Commentary 1; Magnus Von Staudingers Kommentar Einleitung par 1-4; Lookofsky UN Convention on Contracts 18. 
instrument that would remove legal uncertainty and provide commercial predictability in this area of the law.

According to its Preamble the Convention is also aimed at removing any obstacles that may exist as a result of provisions in existing conventions that do not adequately deal or provide for electronic communications. This issue was mentioned at an early stage of UNCITRAL's work and culminated in a report of the Working Group at its $40^{\text {th }}$ Session in 2002 outlining a number of conventions that may be relevant, together with comments on each of these conventions. ${ }^{36}$ Although the value of the survey was recognised by many commentators, the Italian delegation concluded: ${ }^{37}$

What is striking in this connection is the absence, among the international legal instruments surveyed, of an instrument for which the proposed omnibus agreement would reach its intended general purpose. All the surveyed legal instruments, in one way or another, seem to require either no action or a very specific action that could not be confined to the mere establishment of the principle of the electronic equivalent, whenever the terms "writing", "signature" and "document" are used. This should by no means lead to the conclusion that an omnibus agreement of the type envisaged in document A/CN.9/WG.IV/WP.89 would be useless; simply, the conclusion appears to be that the need for such an agreement is rather residual ...

At its $40^{\text {th }}$ Session the Working Group, mindful of the Italian submission, analysed each of the international instruments mentioned in the earlier report with a view to possible action that may be needed. ${ }^{38}$ This analysis, based on a provisional analysis by the Secretariat, leads to the current formulation of article

36 See Legal barriers to the development of electronic commerce in international instruments relating to international trade Compilation of comments by Governments and international organizations A/CN.9/WG.IV/WP.94 (14 February 2002).

37 Legal barriers to the development of electronic commerce in international instruments relating to international trade Compilation of comments by Governments and international organizations A/CN.9/WG.IV/WP.98.

38 Report of the Working Group IV (Electronic Commerce) on the work of its $40^{\text {th }}$ session (Vienna, 14-18 October 2002) A/CN.9/527. 
20, which lists six international instruments in respect of which the UNECIC will apply directly. ${ }^{39}$

In respect of any other international instrument (including those mentioned in the Working Group reports) states have the option in terms of article 20(2) of excluding the application of the UNECIC to those conventions in accordance with the procedures set out in article 21 . It does not require a crystal ball to predict that if there should be widespread use of article 20(2) exclusions, the result would cause a fair amount of legal uncertainty, rather than the legal certainty aimed at. It is to be hoped that states will show restraint in making use of this exclusion in the interests of uniformity and legal certainty, which remains one of the main objects of the Convention.

\subsection{Scope of application}

Although UNCITRAL had already provided some instruments dealing with electronic commerce, namely the Model Law on Electronic Commerce (1996) ${ }^{40}$ and a Model Law on Electronic Signatures (2001), ${ }^{41}$ these model laws were aimed at facilitating the drafting of national legislation applicable to domestic transactions. Those model laws were therefore not drafted specifically with international or commercial trade in mind. As was mentioned above, the need for an international instrument which made specific provision for international commercial trade was expressed despite the availability and success of the model laws.

39 The six conventions are the following: Convention on the Recognition and Enforcement of Foreign Arbitral Awards (New York, 10 June 1958); Convention on the Limitation Period in the International Sale of Goods (New York, 14 June 1974) and Protocol thereto (Vienna, 11 April 1980); UN Convention on Contracts for the International Sale of Goods (Vienna, 11 April 1980); UN Convention on the Liability of Operators of Transport Terminals in International Trade (Vienna, 19 April 1991); UN Convention on Independent Guarantees and Stand-by Letters of Credit (New York, 11 December 1995); UN Convention on the Assignment of Receivables in International Trade (New York, 12 December 2001)

40 Adopted by UNCITRAL on 12 June 1996. See G.A.Res.51/162, adopted on 16 December 1996, UN Doc.A/RES/51/162 (30 January 1997).

41 Adopted by UNCITRAL on 5 July 2001. See G.A.Res56/80 adopted on 12 December 2001, UN Doc.A/RES/56/80 (24 June 2002). 
The scope and field of application of the convention is dealt with in articles 1 and 2:

(a) UNECIC, domestic law and private international law

In the case of most international conventions, the conventions operate on the international level, that is, it regulates the rights and duties of states vis-à-vis the convention parties. The UNECIC, like the CISG, operate in a slightly different fashion. States who have adopted these conventions are bound to introduce the provisions of these conventions as domestic law within their respective areas of jurisdiction. In that sense the CISG has become a body of domestic sales law applicable to international transactions within each of the countries which are members of that convention. Within these states, therefore, there exist two parallel sets of sales law, one applicable to domestic sales and on applicable to international sales and which do not overlap in their field of application. Similarly, the UNECIC will become domestic law which creates rights and obligations for parties in international commercial transactions. If adopted in South Africa, for instance, it will form a body of law applicable to international transactions to the exclusion of the Electronic Communications and Transactions Act (ECT Act). ${ }^{42}$

In any international transaction, therefore, the UNECIC will not apply automatically as public international law, but will only be applicable if according to the rules of private international law that is applied, the transaction is made subject to a legal system where the UNECIC applies. For example, trader A, which has its place of business in Senegal, has concluded a transaction electronically with trader B, which has its place of business in South Africa. For purposes of the example, assume that Senegal has adopted the UNECIC and South Africa not. The first question to be asked if there should be any dispute between the parties on the formation of the agreement is which legal system governs the formation and validity of this agreement. That question is usually answered by the rules of private international law of the lex fori, that is, the 
court which is adjudicating the dispute. ${ }^{43}$ If the rules of private law should determine that Senegalese law should be applied, then the UNECIC will be applicable; if those rules determine that South African law is the proper law of the contract, then the UNECIC will not apply as it is not part of South African law.

This fairly straightforward position in respect of applicability has unfortunately been complicated by the provision of a declaration aimed at reciprocity in terms of article 19, which is similar to the position under article 95 of the CISG. ${ }^{44}$ In terms of article 19 a state may declare that the UNECIC will only apply if both parties have their places of business in Contracting states, that is, states which have adopted the UNECIC. Applied to our example above, if Senegal should have made such a declaration, the UNECIC would not apply even if the applicable law was Senegalese law. The court would exclude the UNECIC and apply domestic Senegalese law to the dispute.

The reason for this exception proffered in the Explanatory Note ${ }^{45}$ makes no sense. It states:

279. The possibility for contracting States to make this declaration has been introduced so as to facilitate accession to the Convention by States that prefer the enhanced legal certainty offered by an autonomous scope of application, which allows the parties to know beforehand, and independently from rules of private international law, when the Convention applies.

The declaration provides no legal certainty as claimed. Whether the UNECIC will apply, will always to an extent be dependent on the rules of private international law and the choice of jurisdiction. If it is certainty that parties want, they can simply choose the applicable law and include or exclude the application of the UNECIC in accordance with the provisions of article 3. 
Article 19 makes provision for further declarations, namely the exclusion of any matter for which the Convention makes provision. In preparing the Electronic Communications Convention, UNCITRAL's aim was to achieve as wide as possible application. ${ }^{46}$ Even though there was consensus that exceptions and reservations should be kept to a minimum, it was also recognised that there were varying degrees of recognition of electronic communications in different legal systems. Although some legal systems recognised the validity of electronic communications, they often still prescribed certain formalities and requirements to ensure legal certainty. ${ }^{47}$ As a result of the differences in approach, and in order to make the convention as acceptable as widely as possible, UNCITRAL decided to allow for these declarations, ${ }^{48}$ which if extensively used by states, will effectively destroy the harmonising effect of this convention.

It is to be hoped that few if any states will make use of these declarations as such declarations unnecessarily complicates the scope and applicability of the UNECIC, as is the case with the CISG. ${ }^{49}$ The issue of reciprocity should really not enter into the discussion as far as the applicability of these conventions is concerned. $^{50}$ Either the policies underlying the acceptance of these conventions are acceptable and desirable in the state involved, or not. The fact that a particular state has adopted the conventions, should indicate assent to these policies and the way in which they have been embodied. The fact that another state has not yet adopted the convention should therefore be irrelevant.

(b) Electronic communications in international transactions

46 See UNCITRAL supra n 33 par 284.

47 Ibid par 284 and 285.

48 Ibid par 284 and 285.

49 See Schlechtriem and Schwenzer (eds) Commentary 3 a 1 par 41-43; a 95 par 1-4; Magnus Von Staudingers Kommentar a 1 par 111-116.

50 The discussion on a 1 and 95 of the CISG is instructive on this issue. See Schlechtriem and Schwenzer (eds) Commentary a 1 par 41-47; Magnus Von Staudingers Kommentar a 1 par 95; Flechtner 1998 Journal of Law and Commerce 187-217; Schlechtriem Uniform Sales Law; also Bell 2005 Singapore Year Book of International Law 55-73. 
Article 1 stipulates that the convention only applies to electronic communications in international transactions, that is, transactions where the parties have their principal places of business in different countries. ${ }^{51}$ However, a transaction will not be regarded as 'international' unless the parties are both aware of this fact before or at the time of the conclusion of the agreement. ${ }^{52}$ The nationality of the parties or whether they are commercial entities or public entities, are facts which are not relevant in the applicability of the UNECIC. ${ }^{53}$ If a government organ, or parastatal or similar body should make use of electronic communications in dealing with a party in another state, the convention will apply.

\section{$4 \quad$ Interpretation of the UNECIC}

One of the major points of criticism against the international harmonisation of law is that such law is very often not uniform or harmonised in its application due to the varying interpretations given to the same provisions by courts in different jurisdictions. ${ }^{54}$ The experience with the CISG, possibly one of the most successful instruments of legal harmonisation to date, however, has shown that the proper collection and dissemination of information, can play an important role in the consistent interpretation and application of a convention. ${ }^{55}$

In the interpretation of an international convention there are a number of aids that may be used by the interpreter, besides the wording of the convention itself. In addition to the wording itself, one is also entitled to have regard to the

51 A 1(1). See the discussion of CISG a 1 in Schlechtriem and Schwenzer (eds) Commentary a 1 par 25-33; Magnus Von Staudingers Kommentar a 1 par 58-71

52 A 1(2). See iro the CISG Schlechtriem and Schwenzer (eds) Commentary a 1 par 48-58; Magnus Von Staudingers Kommentar a 1 par 72-80.

53 A 1(3). Schlechtriem and Schwenzer (eds) Commentary a 1 par 59-61; Magnus Von Staudingers Kommentar a 1 par 123-125.

54 Rosett 1984 Ohio State LJ 265-305 http://www.cisg.law.pace.edu/ 8 Aug; Stephan 1999 http://ssrn.com/abstract=169209 8 Aug; Ferrari 1994 Georgia JICL 183-228 http://www.cisg.law.pace.edu/ 8 Aug; and Ferrari 1999 Journal of Law and Commerce 245-261. However see also Van Alstine 1998 Univ Pennsylvania LR 687-793 http://www.cisg.law.pace.edu/ 8 Aug; Andersen 1998 Pace ILR 403-410 http://www.cisg.law.pace.edu/ 8 Aug.

55 Schlechtriem and Schwenzer (eds) Commentary a 7 par 14-16; Magnus Von Staudingers Kommentar a 1 par 20-32a. 
legislative history of the convention, its so-called travaux préparatoires. ${ }^{56}$ The UNECIC also contains two internal aids for its interpretation: a definitions provision (article 4) and a general interpretative provision in article 5.

Article 5 provides, firstly, that in the process of interpreting the CISG regard must be had to its international character, the need to promote uniformity and the observance of good faith in international law, and secondly that any gaps in the Convention are to be filled in conformance with the general principles underlying the Convention. It is only where there are no such principles which can fill the gap, that resort may be had to the applicable domestic law. ${ }^{57}$

The commentary states: ${ }^{.5}$

107. The principles reflected in article 5 of the Electronic Communications Convention have appeared in most of the UNCITRAL texts, and its formulation mirrors article 7 of the United Nations Sales Convention. The provision is aimed at facilitating uniform interpretation of the provisions in uniform instruments on commercial law. It follows a practice in private law treaties to provide self-contained rules of interpretation, without which the reader would be referred to general rules of public international law on the interpretation of treaties that might not be entirely suitable for the interpretation of private law provisions (see A/CN.9/527, para. 124).

Any potential gaps in the UNECIC are therefore to be filled in accordance with the provisions of article 5(2). A gap can be said to exist if the UNECIC does not expressly make provision for a matter which falls within the scope of its application. ${ }^{59}$ The first step therefore, is to determine whether the issue at hand falls within its scope according to the provisions of articles 1 to 4 . If the matter is one that falls inside its scope, then the gap must be filled either in conformity

56 Vienna Convention on the Law of Treaties, 1969 a 32; Dugard International Law 339; Schlechtriem and Schwenzer (eds) Commentary a 7 par 24-26.

57 A 5(2). This provision is identical to a 7 of the CISG which may also be of assistance in the interpretation of a 5(2).

58 Supra n 33 par 107.

59 Schlechtriem and Schwenzer (eds) Commentary a 7 par 27-29; Magnus Von Staudingers Kommentar a 7 par 38-39. 
with the underlying principles of the convention or, where no such principles exist or can be discerned, on the basis of the gap-filling domestic law. ${ }^{60}$

Although provisions like article 5 have become common place in UNCITRAL texts, at the time that article 7(2) of the CISG was discussed, its inclusion was controversial as many delegations regarded such an approach to be too vague and unrealistic because such underlying principles had not been clearly formulated. ${ }^{61}$ The fact that it is now commonly included in the UNCITRAL texts without much discussion, bears testimony to the fact that the fears expressed at the CISG diplomatic conference, were largely unfounded. The case law and commentary have developed a number of underlying principles which can and have been applied in order to fill gaps in the CISG.

Magnus did ground breaking work in identifying a number of these underlying principles for the CISG. ${ }^{62}$ He states that there are four different ways in which these general principles can be derived from a convention: ${ }^{63}$

- Some principles expressly state their applicability to the whole of the convention; for instance the principles of harmonization and unification, legal certainty, commercial predictability, freedom of the parties, technological neutrality, functional equivalence, internationality and good faith are contained in the preamble and in article 5. These principles were also regularly discussed during the formative stages of the convention.

- Some principles are contained in a number of provisions, but may be absent from provisions where one would have expected them. That gap can then be filled by reference to that principle.

- In some cases a single provision may contain a principle which can be of general application. Obvious examples are article 3 which contains the

60 A 5(2). See iro the CISG Schlechtriem and Schwenzer (eds) Commentary a 7 par 30-34; Magnus Von Staudingers Kommentar a 7 par 41-57.

61 Schlechtriem and Schwenzer (eds) Commentary; Honnold Uniform Words and Uniform Application 143-135; Magnus Von Staudingers Kommentar a 7 par 6-10.

62 Magnus 1995 RabelsZ 469-494.

63 Magnus 1995 RabelsZ 470-473; and Magnus Von Staudingers Kommentar a 7 par 49. 
principle of party autonomy; article 5 which contains the principles of good faith, internationality and uniformity.

- The overall context of the convention may indicate that a general principle is assumed. Magnus refers to the pacta sunt servanda principle contained in the CISG, but which is nowhere expressed. In the UNECIC the principle of reasonable reliance can be assumed from the overall context of the Convention, although those terms are not specifically used anywhere.

In a similar fashion by deductive reasoning and analysis of the provisions of the Convention, and by looking at the legislative history of the UNECIC, a number of general underlying principles can be discerned.

\subsection{Internationality, harmonization, unification and autonomous interpretation}

From the outset it was recognised that the UNECIC should become an international instrument with the aim of harmonizing the use of electronic communications in international trade. ${ }^{64}$ This is repeated throughout the working history of the Convention and its acceptance. In the declaration to the adoption of the UNECIC, the General Assembly states:

The General Assembly, Recalling its resolution 2205 (XXI) of 17 December 1966, by which it established the United Nations Commission on International Trade Law with a mandate to further the progressive harmonization and unification of the law of international trade and in that respect to bear in mind the interests of all peoples, in particular those of developing countries, in the extensive development of international trade,

Recalling that, at its thirty-fourth session, in 2001, the Commission decided to prepare an international instrument dealing with issues of electronic contracting, which should also aim at removing obstacles to electronic commerce in existing uniform law conventions and 
trade agreements, and entrusted its Working Group on Electronic Commerce with the preparation of a draft.

This principle is also expressly stated in the Preamble of the Convention:

Desiring to provide a common solution to remove legal obstacles to the use of electronic communications in a manner acceptable to States with different legal, social and economic systems,

The principle of internationality and autonomous interpretation is expressly contained in article 5 (quoted above) which deals specifically with the interpretation of the Convention and filling any gaps in it. ${ }^{65}$

In the application of the UNECIC courts and tribunals should therefore opt for interpretations and solutions for filling gaps that are in conformance with and will promote the international character of the Convention, uniformity and harmonisation. It always remains a concern with all instruments of harmonisation that courts and tribunals will negate the harmonising effect with decisions showing a homeward trend or coloured by domestic influences. It is a topic that has been thoroughly discussed in regard to the CISG. ${ }^{66}$ Vogel, Shannon and Doernberg remark that there are two problems with foreign decisions: ${ }^{67}$

As a practical matter, decisions of other states can be inconsistent. ... Moreover, because it would conflict with national sovereignty, even a majority or uniform legal view of foreign courts cannot be considered binding.

It is commonly accepted that courts will not be bound by the decisions of courts of foreign jurisdictions. ${ }^{68}$ However it is important for the uniform application of

\section{Supra n 33 par 107.}

66 Schlechtriem and Schwenzer (eds) Commentary a 7 par 14; Enderlein and Maskow International Sales Law 14-15, 55; Case law: Germany Frozen pork case http://cisgw3.law.pace.edu/cases/050302g1.html 6 Aug.

67 Vogel, Shannon and Doernberg Income Tax Treaties 30.

68 Schlechtriem and Schwenzer (eds) Commentary 97-98; Magnus Von Staudingers Kommentar 174; Bianca and Bonell Commentary 91. However, see also Rosett 1984 Ohio State LJ 265-305 http://www.cisg.law.pace.edu/ 8 Aug; Rabinowitz 1993 Lex Mundi World Reports 7. 
the CISG that due consideration should be given to foreign authority, even if not binding. Schlechtriem states: ${ }^{69}$

[C]ourts can be expected, if not to follow the theory of stare decisis, in any event to have benevolent regard to foreign court decisions on the matter.

These sentiments are echoed in the Italian Agricultural products case where the court remarks: ${ }^{70}$

[The CISG] also requires that, at the moment of the delivery, the object of the sale be movable and tangible, as stressed by Italian jurisprudence (See Trib. Rimini, supra; Trib. Pavia, supra) as well as by foreign jurisprudence (See OLG Köln [Germany], 26 August 1994, in Neue Juristische Wochenschrift Rechtsprechungs-Report, 1995, 246; Cour d'appel de Grenoble [France], 26 April 1995, available at $<$ http://witz.jura.uni-sb.de/CISG/decisions/2604952v.htm>). Although not binding, as the minority view wishes, however, the jurisprudence on the Convention must be very carefully considered in order to assure uniformity in the application of [CISG], as required by its Art. 7(1). In fact, the mere autonomous interpretation of [CISG] -interpretation that does not refer to the meaning attributed to specific expressions by a particular national regulation -- is by itself inadequate to assure the uniformity to which [CISG] aims in order to promote the development of international trade.

\subsection{Trade facilitation}

A second stated aim of the UNECIC which also forms an underlying principle is that of facilitating international trade. ${ }^{71}$ In the Preamble of the Convention it is expressly stated as follows:

69 Schlechtriem 1983 Israel LR 325-326. See also: Honnold Uniform Words and Uniform Application 120-124; Kastely 1988 NW J Intl L \& Bus 594; Audit Vienna Sales Convention 154-155; Maskow "The Convention" 54; and Enderlein and Maskow International Sales Law at 56 who state: "What matters here is not a prejudicial effect of rulings by foreign courts or arbitrational tribunals and not that the decision taken by an organ, which by accident was entrusted first to deal with a specific legal issue, is attached a particular great importance; rather the existing material in regard to relevant rulings has to be taken account of when giving the decision."

70 Case law: Italy Agricultural products case http://cisgw3.law.pace.edu/cases/040225i3.html 8 Aug.

71 See par 3 and 4 of the Preamble to the General Assembly's adoption quoted above. 
Noting that the increased use of electronic communications improves the efficiency of commercial activities, enhances trade connections and allows new access opportunities for previously remote parties and markets, thus playing a fundamental role in promoting trade and economic development, both domestically and internationally,

Convinced that the adoption of uniform rules to remove obstacles to the use of electronic communications in international contracts, including obstacles that might result from the operation of existing international trade law instruments, would enhance legal certainty and commercial predictability for international contracts and help States gain access to modern trade routes.

The principle is also contained in article 8(1) which provides:

8(1). A communication or a contract shall not be denied validity or enforceability on the sole ground that it is in the form of an electronic communication.

\subsection{Legal certainty and commercial predictability}

The principle of legal certainty was one of the driving forces of the UNECIC from the outset and remained one of the stated objects. ${ }^{72}$ In the Preamble to the Convention it is stated:

Considering that problems created by uncertainty as to the legal value of the use of electronic communications in international contracts constitute an obstacle to international trade,

Legal certainty, however, is a principle that needs to be balanced with reference to other principles such as flexibility, good faith and internationality which introduce a measure of uncertainty due to their generalised nature. Legal certainty for instance underlies the following provisions:

72 See the par 3 and 4 of the Preamble to the General Assembly's adoption (quoted above); par 3 and 4 to the Preamble to the Convention; the Report of the Working Group on Electronic Commerce on the Work of its $38^{\text {th }}$ Session (New York 12-23 March 2001) A/CN.9/484 (24 April 2001). 
- Article 7: resort to domestic law on requirements on parties to disclose their identities, places of business or other information; and legal consequences for making misrepresentations);

- Article 8: legal recognition of electronic communications.

\subsection{Technological neutrality}

The fifth paragraph of the Preamble contains two of the most important principles underlying the Convention and which guided the work of UNCITRAL throughout the drafting process, namely technological neutrality and functional equivalence: $:^{73}$

Being of the opinion that uniform rules should respect the freedom of parties to choose appropriate media and technologies, taking account of the principles of technological neutrality and functional equivalence, to the extent that the means chosen by the parties comply with the purpose of the relevant rules of law.

These principles also provided important guidance to the two sister instruments developed by UNCITRAL prior to the Convention, namely the two Model Laws. ${ }^{74}$ It forms the substratum for all of the domestic legislation that have adopted or used the model laws mentioned above.

The Secretariat explains the principle as follows: ${ }^{75}$

47. The principle of technological neutrality means that the Electronic Communications Convention is intended to provide for the coverage of all factual situations where information is generated, stored or transmitted in the form of electronic communications, irrespective of the technology or the medium used. For that purpose, the rules of the Convention are "neutral" rules; that is, they do not depend on or presuppose the use of particular types of technology and could be applied to communication and storage of all types of information.

The principle is important because of the speed at which technological advances are taking place, a problem which is compounded by the

73 See supra n 33 par 46; Connolly 2006 Computer Law \& Security Report 32.

74 UNCITRAL 1996 Guide to Enactment with a 5 bis as adopted in 1998 par 2 and 3; and UNCITRAL 1991 Model Law on Electronic Signature.

75 Supra n 33 par 47. 
convergence between different types of technology. Until fairly recently the dividing line between voice communications and so-called pure electronic data messages was easy to perceive. This dividing line is being eroded quite quickly with many automated systems making use of pre-recorded automated voice messages and data systems which can recognise and react to voice prompts. ${ }^{76}$ It is becoming very difficult to exclude voice messages as electronic messages. The definitions of 'data message' and 'electronic communication' in article 4 are certainly wide enough to include voice messages used in an automated environment. $^{77}$

\subsection{Functional equivalence}

This principle is also one of the expressly stated principles in the Preamble of the Convention. ${ }^{78}$

The principle of functional equivalence is closely related to the principle of technological neutrality, but the emphasis is different: the latter is aimed at drafting which will avoid that the Convention will become dated, whereas the former is aimed at ensuring that there is as little difference as possible in the manner in which the law regards and deals with traditional methods of communication and electronic communications.

It is also important that the legal regime applicable to traditional paper based forms of communication, should not differ significantly in respect of electronic communications. ${ }^{79}$ Functional equivalence strives to create legal results which are similar if not identical, regardless of the medium of communication.

\subsection{Freedom of contract}

The principle of freedom of contract or party autonomy is contained in article 3 which stipulates:

77 It remains an open question on whether these definitions are not so wide that they include all voice communications, including live person to person communications over the telephone or internet. Such an interpretation may cause havoc in regard to the interpretation and application of a 9 in terms of which such communications will be deemed to be in writing where it is recorded.

78 Preamble par 5. See also Connolly 2006 Computer Law \& Security Report 32.

79 Supra n 33 par 46. 
Article 3 Party autonomy

The parties may exclude the application of this Convention or derogate from or vary the effect of any of its provisions.

During the drafting phase, UNCITRAL was aware that in practice the parties very often solved issues of legal uncertainty by making appropriate provision in their contract for those issues. Article 3 recognises that the solutions chosen by the party should take precedence over any of the provisions of the Convention. ${ }^{80}$ Party autonomy is a principle that not only features strongly in this convention, but also in the CISG ${ }^{81}$ In the commercial contractual sphere, there exists in most legal systems a very high degree of contractual freedom, allowing parties to regulate their affairs in accordance with their own needs and understanding and with very little statutory interference.

\subsection{Good faith}

Good faith as a requirement in the interpretation of the UNECIC in terms of article 5, caused much less controversy than its inclusion in article 7 for similar purposes in the CISG. ${ }^{82}$ This may partly be ascribed to the fact that the use of good faith principle in the application of the CISG, even as a substantive principle in the conclusion and performance of the contract, has not caused the legal uncertainty feared by many (mainly common law) countries, ${ }^{83}$ but also to the fact that this Convention contains a fairly limited number of substantive law

80 See also the Preamble par 5; UNCITRAL supra n 33 par 84-87.

81 See a 6; Magnus Von Staudingers Kommentar 149-150; Schlechtriem and Schwenzer (eds) Commentary 83-84.

82 See the discussion and differing viewpoints: Schlechtriem and Schwenzer (eds) Commentary a 7 par 17-18; Magnus Von Staudingers Kommentar a 7 par 24-29; Farnsworth TLDB http://tldb.uni-koeln.de/ 8 Aug; Flechtner Pace ILR 295-337; Case law: Germany Circuit boards case http://cisgw3.law.pace.edu/cases/981005g1.html 8 Aug; Case law: Hungary Mushrooms case http://cisgw3.law.pace.edu/cases/951117h1.html 8 Aug; Bianca and Bonell Commentary 84-85; Enderlein and Maskow International Sales Law 2.1; Honnold Uniform Law for International Sales 99-100; Case law: Belgium NV A.R. v. NV I. http://cisgw3.law.pace.edu/cases/020515b1.html 8 Aug; Case law: Spain Motors case http://cisgw3.law.pace.edu/cases/030922s4.html 8 Aug; Case law: Netherlands Rynpoort Trading v. Meneba Meel 8 Aug.

83 See generally Schlechtriem and Schwenzer (eds) Commentary 95, Magnus Von Staudingers Kommentar 170, 175; Magnus 1995 RabelsZ 469-494. 
provisions. $^{84}$ The Secretariat remarks that this provision has become fairly standard in most UNCITRAL instruments. ${ }^{85}$

The good faith principle is of necessity a fairly wide and imprecise instrument that will require judicial interpretation and precision over time. In respect of the CISG there is broad agreement that article 7(1) at least contains a prohibition against abuse as well as a prohibition against actions contrary to prior conduct, similar to estoppel in Common Law. ${ }^{86}$

\subsection{Protection of reasonable reliance}

The principle of good faith is closely related to the principle that protects reasonable reliance. Where one party has created an impression on which the other party relies, the reasonable reliance of the latter should be protected by the law. ${ }^{87}$ The following instances of the protection of reliance can be found in the Convention:

- Article 6(1)-(2): Presumed location of the party according to its indication or circumstances known and contemplated by the parties;

- Article 9(2)-(3): Giving legal recognition to electronic communications and signatures where the parties intended and relied thereon.

\subsection{Freedom of form}

The point of departure is that there are no form requirements in terms of this Convention (article 9(1)), but it is recognised that certain states may have mandatory statutory requirements for certain transactions such as writing or signature. $^{88}$ In respect of such transactions article $9(2)$ provides that an

84 Connolly 2006 Computer Law \& Security Report 32.

85 Supra n 33 par 107.

86 Magnus 1995 RabelsZ 469-494.

87 Iro the CISG see Magnus 1995 RabelsZ 469-494.

88 The following countries have made an Article 96 declaration under the CISG requiring writing: Argentina, Belarus, Chile, China, Hungary, Latvia, Lithuania, Paraguay, Russia and the Ukraine. The Chinese reservation, however, is a curious one. At the time there were formal requirements for contracts under Chinese law, but since 1999 the Chinese Uniform Contract Law, which repealed the previous enactments requires no formalities. See Wang and Andersen 2004 Vindobona JICL \& A 148. 
electronic communication will meet any domestic requirement for writing provided that it is available for subsequent reference. The Secretariat Commentary states: ${ }^{89}$

Paragraph 1 of article 9 of the Electronic Communications Convention reflects the general principle of freedom of form, as stated in article 11 of the United Nations Sales Convention, with a view to making it clear that the reference to possible form requirements under other law does not imply that the Electronic Communications Convention itself establishes any form requirement.

\subsection{Physical location of the parties}

The fact that electronic communications take place in cyberspace, is often cited as a factor which causes legal uncertainty because it may be very difficult to establish the locality of the other party, that is, is it its place of business, place of residence or the place where its information system or server is situated. ${ }^{90}$ The Secretariat Explanatory Note remarks:

109. Considerable legal uncertainty is caused at present by the difficulty of determining where a party to an online transaction is located. While that danger has always existed, the global reach of electronic commerce has made it more difficult than ever to determine location. This uncertainty could have significant legal consequences, since the location of the parties is important for issues such as jurisdiction, applicable law and enforcement. Accordingly, there was wide agreement within UNCITRAL as to the need for provisions that would facilitate a determination by the parties of the places of business of the persons or entities they had commercial dealings with. ${ }^{91}$

It is generally recognised that the location of the information system and server is not a useful connecting factor as there physical location may be spread out

89 Supra $\mathrm{n} 33$ par 136.

90 Supra n 33 par 109; Raymond 2006 The Computer \& Internet Lawyer 9; Connolly 2006 Computer Law \& Security Report 36-37.

91 UNCITRAL Secretariat Explanatory Note http://www.uncitral.org/ 8 Aug par 44. 
over various jurisdictions or may be entirely fortuitous or irrelevant as far as the parties are concerned. ${ }^{92}$

\section{$5 \quad$ Critical exposition of provisions}

A number of provisions of the UNECIC have already been discussed above and will not be considered again in this section.

\subsection{Definitions}

Most of the definitions contained in this section are based on the definitions contained in the earlier Model Law on Electronic Commerce. These definitions are meant as an interpretational aid in an area where many of the terms may have a fairly technical meaning. ${ }^{93}$

A key definition is that of 'data message' which is essential in determining the scope of the UNECIC. It reads:

(c) "Data message" means information generated, sent, received or stored by electronic, magnetic, optical or similar means, including, but not limited to, electronic data interchange, electronic mail, telegram, telex or telecopy.

The definition is aimed at including all forms communication that are generated, transmitted and stored in paperless form. ${ }^{94}$ It is clearly stated that the examples are not exhaustive, but merely illustrative. This is important to make provision for newer technologies that may develop in future.

Strictly speaking this definition is wide enough to include telephonic conversations, but the fact that it is not mentioned as one of the examples probably is an indication that it should be excluded. Telephonic conversations

92 Supra n 33 par 109; Raymond 2006 The Computer \& Internet Lawyer 9; Connolly 2006 Computer Law \& Security Report 36-37.

93 Compare this relatively short list with the extensive list contained in the ECT Act 25 of 2002 s 1.

94 Supra n 33 par 95-96. 
are problematic due to the convergence of technologies and the fact that more and more automated systems are making use of recorded voice to interact with natural persons. One must probably conclude that where to natural persons are conversing telephonically or by protocols such as Voice over Internet Protocol (VolP) such messages should be excluded form the definition of data message, even where recorded. ${ }^{95}$ Where a natural person is conversing interactively with an automated system, such communications should be regarded as data messages. Until such time as interpreted by the courts there will remain a measure of uncertainty about this aspect.

The following definitions are also significant:

- 'Originator' This definition is important for purposes of ascribing the message to a specific person, that is, the person who should be deemed to have made the communication or should be held responsible for it. It furthermore makes it clear that internet service providers (ISPs) are not to be regarded as agents of the person to whom they are providing the service. ${ }^{96}$

- 'Addressee' This definition is aimed at ensuring to provide certainty as to who should be regarded as the person entitled to receive the message. Again it is clearly stated that ISPs are mere conduits and not to be regarded as agents in any sense. ${ }^{97}$

- 'Place of business' This definition is important to ensure that the physical locality of the parties can be established with certainty and without getting ensnared in the debate which may arise about the location of a party where it maintains a server or service provider at a place somewhere else than its usual place of business. This issue is important for purposes of jurisdiction and the place of contracting. ${ }^{98}$ 


\subsection{Location of the parties: article 6}

The various sections of article 6 aim at ensuring that there is certainty about the physical locality of each of the parties. ${ }^{99}$ Usually the physical place will be deemed to be the place indicated by that particular party. Therefore, even if a party does not have a physical presence at the place indicated by it as its usual place of business, it may be deemed to be its place of business to protect the reliance of the other party on that fact. ${ }^{100}$ However, the article also stipulates that a party may prove that the other party has a place of business somewhere else. This may for instance be important where the party has deceptively indicated a place of business at a location where it has no assets or to escape some other restraint. The innocent party then has a choice to elect which place of business it will rely on. This may be especially important for purposes of jurisdiction and legal proceedings. ${ }^{101}$

This provision is also at pains to point out that the fact that a party maintains certain equipment such as a server for example at a specific place, does not cause that place to be deemed its place of business. If a natural person has no place of business as defined in this article, his or her usual place of residence will be the relevant place for purposes of the Convention. ${ }^{102}$

The domain name used by a party can also not be used to determine its place of business as such domain names can be misleading. The fact that a party has a domain name ending in .uk or .za does not necessarily mean that it has any presence in either the United Kingdom or South Africa, respectively. ${ }^{103}$

\subsection{Information requirements: article 7}

Article 7 provides that nothing in the convention must be understood to relieve a party from its obligations or liability to disclose its identity, places of business

99 Supra n 33 par 109. See s 23(c) of the ECT Act 25 of 2002 for a provision with similar aim.

100 Supra n 33 par $110-112$.

101 Supra n 33 par 109.

102 Supra n 33 par 117.

103 Supra n 33 par 117. 
or other information, or relieves a party from the legal consequences of making inaccurate, incomplete or false statements in that regard. Parties will therefore still have to comply with any local legislation in this regard.

During the drafting discussions it was considered that obligations to disclose certain information would be more appropriately placed in international industry standards or guidelines, rather than in an international convention dealing with electronic contracting. ${ }^{104}$

\subsection{Legal recognition article 8}

Article 8 stipulates that electronic communications will be given legal effect on a par with other traditional forms of communications. The mere fact that a statement is sent as a data message cannot serve as a ground for its nonrecognition. In this way article 8 aims at establishing technological neutrality as far as the form or method of business communications are concerned. ${ }^{105}$ This does not mean that such communications cannot be impugned on some other ground such as fraud or mistake.

The UNECIC intentionally refrained from establishing rules in respect of the place and time of the formation of agreements, leaving this aspect to be established by the applicable domestic law. ${ }^{106}$ It is in instances like this where there may be a symbiotic relationship between the provisions of the UNECIC and those of the CISG, if applicable. In terms of the CISG contracts are deemed to be concluded at the time and place where and when the offeror receives notice of the acceptance. ${ }^{107}$

However, for purposes of establishing where and when communications are deemed to be legally effective, article 10 contains deeming provisions which are relevant. They will be discussed below.

104 Supra n 33 par 126.

105 Supra n 33 par 129. See s 11 of the ECT Act 25 of 2002 for a similar provision with a similar aim.

106 Supra n 33 par 130.

107 A 24 read with a 18(2). 


\subsection{Time and place: article 10}

The time and place of communications may be important for a number of reasons, including the time and formation of the agreement or the lapsing of an offer or some other time limit such as the time for performance. In terms of article 10(1) a message is deemed sent if it leaves the information system used by the originator, that is, when the message is beyond the control of the originator. ${ }^{108}$ If the parties are making use of the same information system, for instance they both use the same ISP, the message is deemed sent when it is received by the addressee. ${ }^{109}$

Conversely in terms of article 10(2) a message is deemed received when it is capable of being retrieved by the addressee at its indicated electronic address. Where the messages are sent to another address, it is deemed received when the addressee becomes aware of the fact that the message has been sent to that address.

As indicated above, the time and place of the contract will still be determined by the applicable local law. A number of different solutions are possible:

- Where the information theory applies. ${ }^{110}$ In terms of this approach the contract is concluded at the time and place where the offeror takes subjective notice of the acceptance. This would mean in this context that the offeror will have had to retrieved the acceptance message and read it. In most legal systems it is now recognised that this is not a suitable approach where one is dealing with indirect forms of electronic communication, that is, any communication other than interactive voice.

108 Supra n 33 par 171-172.

109 See s 23 of the ECT Act 25 of 2002 for a corresponding provision.

110 For a general discussion of these theories see Christie Law of Contract 76-85; Cape Explosive Works $v$ SA Oil and Fat Industries 1921 CPD 244; Kergeulen Sealing \& Whaling v CIR 1939 AD 487; Jamieson v Sabingo 2002 (4) SA 49 (SCA) par 5; Van der Merwe et al Contract General Principles 66. The general approach in South African law is based on the information theory as point of departure. 
- Where the postal or despatch theory applies. ${ }^{111}$ This theory which applies in Anglo-American legal systems (but also South Africa) provides that the contract is deemed to be concluded at the time and place where and when the acceptance is posted (sent). This would mean that the contract would be deemed concluded at the time that the data message leaves the information system of the offeree and the place of business of the offeree. It is generally recognised that the despatch theory is outdated and unsuited to the modern electronic market place. In South Africa the ECT Act 25 of 2002 has rejected this approach as far as electronic communications are concerned opting for the reception theory. ${ }^{112}$

- The reception theory. This is the theory which is generally applied in civil law countries and which has also been adopted in South Africa in respect of electronic communications. ${ }^{113}$ In terms of this theory the contract is deemed to be concluded at the time that the acceptance is received by the offeror and at that place. This is also the approach adopted in the CISG. ${ }^{114}$ In terms of article 18(2) read with article 23 the contract is deemed concluded when the acceptance 'reaches' the offeror. Article 24 determines that a message is deemed to have reached the offeror where it is delivered to its address.

Although there is a resort to domestic law to determine the time and place of contracting, in many instances the referral to domestic law will in actual fact be a referral to the CISG in which case there should be a uniform approach to the time and place of the formation of the contract.

\subsection{Form - writing and signature: article 9}

111 Christie Law of Contract 76-85; Cape Explosive Works v SA Oil and Fat Industries 1921 CPD 244; Kergeulen Sealing \& Whaling v CIR 1939 AD 487; Jamieson v Sabingo 2002 (4) SA 49 (SCA) par 5; Van der Merwe et al Contract General Principles 66.

112 See s 22(2).

113 Supra n 33 par 174.

114 See a 18(2). Schlechtriem and Schwenzer (eds) Commentary a 18 par 11-12; Magnus Von Staudingers Kommentar a 1 par 14. 
This provision which deals with formalities is a key provision in the context of electronic business communications. The point of departure, as is the case with the CISG, is that no formalities are required for the validity of any message. ${ }^{115}$ The provision recognises however, that in some legal systems writing may be required as a formality. In line with the principle of functional equivalence, ${ }^{116}$ article 10(2) stipulates that where domestic law requires a communication to be in writing, that a data message will be deemed to be in writing provided that the information in such a communication is accessible for subsequent reference. Practically speaking this means that the data message must be capable of being stored and must in fact be stored. Transient data messages which are not capable of being stored or which are not stored will not meet the writing requirement in terms of this provision.

One of the early fears in respect of data messages centred on the fact that data messages could be altered with relative ease and without any apparent sign. It is now generally recognised that these fears were somewhat exaggerated and that with proper record keeping practices and utilising security methods now freely available, that the opportunity for fraud is no greater than with original paper documentation. ${ }^{117}$ Paper documents fulfil a number of evidentiary functions which can easily be mimicked by data message techniques available. These functions include the keeping of a record that cannot easily be altered by one of the parties; providing original copies to both parties; authentication of the document through signature; and having documentation available that would be acceptable to courts and public authorities. ${ }^{118}$

The needs of both business and government have in a practical sense caused the acceptance of electronic documents or data messages to replace paper documents. Using proper security techniques and data storage practices, data

115 See CISG a 11 and 12. Schlechtriem and Schwenzer (eds) Commentary a 11 par 3-4; Magnus Von Staudingers Kommentar a 11 par 4-6.

116 See UNCITRAL supra n 33 par 133. The CISG also contains provisions recognising that writing may be required by a country. See a 12 and 96 . Schlechtriem and Schwenzer (eds) Commentary a 12 par 2-3; Magnus Von Staudingers Kommentar a 12 par 8-11; a 96 par 7.

117 Supra n 33 par 151-154.

118 See UNCITRAL supra n 33 par 133. 
messages do not only equal these functions of paper documents but far outstrip them. ${ }^{119}$ Article 9 provides the minimum requirements that need to be met for these purposes. The parties may stipulate their own requirements in their agreement. Parties should also be aware that the law of evidence in many countries may have additional requirements that need to be observed.

Article 10(4) deals with the requirements for integrity and reliability of data messages. It stipulates that where domestic requires a document to be retained in its original form, that requirement is deemed met if a reliable assurance exists as to the integrity of the information as first generated in its final form. ${ }^{120}$ Such information must be capable of being displayed to the person to whom the information must be available. Article 10(5) states the material requirements for judging the integrity of such information: it must prove that the information has remained complete and unaltered apart from any endorsement or changes that are naturally associated with the transmission, storage or display of the information. The standard of proof necessary will be relative to the purpose for which the information was generated and all the relevant circumstances.

The manner in which electronic information is handled within any business will depend on the nature and importance of such information. In the light of the above requirements companies must develop protocols for dealing with information, its authentication, security and storage which will tend to prove the authenticity of such information. The requirements stipulated by the UNECIC are reasonable and practical. It also takes into account technological changes and advances. Information handling and storing protocols should therefore be revised from time to time to make provision for newer and better authentication techniques.

\subsection{Invitations, advertisements and offers: article 11}

The problem whether a website offering goods or services for sale constitutes an offer or not, is not restricted to electronic communications and websites, but 
is a much older problem. ${ }^{121}$ The point of departure in most legal systems is that advertisements usually do not constitute an offer open to the public, but is simply an invitation to do business. ${ }^{122}$ The offer is made by the person reacting to such an invitation and can therefore be accepted or rejected by the advertiser.

The use of internet trading has taken this problem a step further though, because many websites are interactive and allows customers to order goods almost instantaneously. The problem only really comes to the fore where the website or advertisement contains an error detrimental to the website trader, for instance where the website inadvertently displays a mistaken price.

Article 11 approaches this problem from the traditional angle, namely that where a website or a proposal to conclude a contract is addressed at the world at large, such a communication is deemed to be an invitation to do business, unless there is a clear indication in the communication that the party making the communication intends to be bound by the acceptance of such an offer. ${ }^{123}$ Practically therefore it will depend on the actual wording and construction of the website or communication whether it is merely an invitation or actually an offer. This is a sensible approach which is in accord with the accepted approach to this problem. ${ }^{124}$

In line with the principle of party autonomy, a web trader can choose which approach it wishes to follow by explicating stating its intention in the communication or on the website. Accordingly web traders should take care that their website does not convey a wrong impression. The simplest method is be clearly stipulating the contractual process to be followed in its standard terms of agreement which should be available online.

121 See for instance Crawley v R 1909 TS 1105; Christie Law of Contract 43-46; 88-89. See also UNCITRAL supra $\mathrm{n} 33$ par 197.

122 Crawley v R 1909 TS 1105; Christie Law of Contract 43-46; 88-89. See also UNCITRAL supra n 33 par 197-199.

123 UNCITRAL supra n 33 par 200-204.

124 See for instance a 14(2) of the CISG. Schlechtriem and Schwenzer (eds) Commentary a 14 par 12-15; Magnus Von Staudingers Kommentar a 1 12-15; Case law: Austria Pork case http://cisgw3.law.pace.edu/cases/020307a3.html 6 Aug. 


\subsection{Automated transactions: articles 12 and 13}

Article 12 is aimed at ensuring legal certainty about another area where traditional contract theory does not provide an immediate or clear answer or where there is a perceived uncertainty in the minds of many internet users. The usual approach to the formation of contract is that there must be subjective consensus or agreement between the parties. This is usually augmented by some approach such as the reliance theory in order to deal with problems caused by misstatements or mistake. ${ }^{125}$ Where the contracting process however takes place by the use of one or more automated systems, where there is no human interaction on at least one part (or on both parts in the case of some EDI systems), traditional theory struggles to explain the binding nature of these automated communications, because there is no subjective agreement or consensus. ${ }^{126}$

Article 12 determines that where a contract is formed by the interaction of an automated message system and a natural person, or by the interaction of automated message systems, it shall not be denied validity or enforceability on the sole ground that no natural person reviewed or intervened in each of the individual actions carried out by the automated message systems or the resulting contract. ${ }^{127}$ The provision in essence attributes the actions of the automated system to the party making use of such automated system. ${ }^{128}$ Accordingly any risks involved in the sue of such automated systems rest with the party using that system. For instance, if the automated system malfunctions and orders an excessive amount of goods, the seller will be entitled to rely on the validity of that order unless its reliance under the circumstances would be unreasonable.

125 See for instance the discussion in Sonap Petroleum SA v Papadogianis 19923 SA 234 (A).

126 See the explanation of Christie Law of Contract 76-78 that in certain circumstances the offeror may dispense with the normal requirement that the offeree's acceptance must be communicated to it. See also UNCITRAL supra n 33 par 211-213.

127 See ECT Act s 20(a)-(d) for a similar provision.

128 Supra n 33 par 211-213. 
The legal validity or enforceability of such erroneous messages can still be challenged, not on the ground that it is an automated system, but on traditional grounds of mistake or lack of consensus. These grounds will depend on the applicable legal system, which in many instances could be the provisions of the CISG. In this regard article 8 of the CISG stipulates that statements made by a party are to be interpreted according to that party's intention where the other party knew or could not have been unaware of what that intention was. What a party knew will depend on the particular circumstances and subjective knowledge of the party. ${ }^{129}$ If the subjective intention cannot be established or be attributed in that manner, the statement must be interpreted according to the understanding of a reasonable person of the same kind and in the same circumstances. In determining the intent of a party or the understanding a reasonable person would have had, due consideration is to be given to all relevant circumstances of the case including the negotiations, any practices which the parties have established between themselves, usages and any subsequent conduct of the parties.

The provisions of article 12 must be read with the provisions of article 14 which deals with errors in electronic communications. Article 14, however, is restricted to situations where a natural person interacts with an automated system. It will therefore not be applicable to transactions such as EDI transactions where both parties are employing automated systems. In terms of this provision natural persons who have made an error in the data message sent, are entitled to withdraw that message and will not be bound by that part of the message. ${ }^{130}$

There are a number of requirements before this provision applies:

- The automated system must have lacked a method or technique whereby the natural person could review and correct any messages. Therefore, if a system is set up whereby it requires the natural person to

129 Schlechtriem and Schwenzer (eds) Commentary a 8 par 12-18; Magnus Von Staudingers Kommentar a 8 par 10-18.

130 UNCITRAL supra n 33 par 224-227. 
review the whole transaction and to confirm its correctness, the natural person will not be able to retract any mistakes.

- The natural person must notify the other party as soon as possible of the mistake after he or she has become aware of the mistake.

- The natural person or the party for whom he or she was acting must not have received a material benefit from the transaction.

Finally article 14 preserves the rights of redress of the innocent party to hold the other party responsible for damages arising due to the mistake or misstatement. Whether such liability arises or is available will depend on the particular applicable domestic law.

The risks of erroneous messages, especially in EDI transactions need to be specifically addressed in the interchange agreement between the parties or the applicable standard terms and conditions. Such systems should also make provision to deal with unusual communications (for instance orders which vary considerably from the usual volumes ordered or to be expected) for individual human vetting. The absence of such mechanisms may make it difficult for a party to rely on the erroneous communication of the other party, because it may be deemed to be unreasonable.

The approach followed in article 14 is a sensible one having consideration to the environment in which it is to operate, that is, outside the realm of consumer contracts where more stringent requirements may be necessary.

\subsection{Availability of terms and incorporation: article 13}

The inclusion of standard terms and conditions of agreement by various techniques such as incorporation by reference, click-wrap and notices displayed in prominent places is something which is handled in a variety of ways in different legal systems. ${ }^{131}$ Many legal systems now also have some

131 See eg s 11(3) of the ECT Act; Christie Law of Contract 199-209; Schlechtriem and Schwenzer (eds) Commentary a 8 par 52-59; Case law: Germany Machinery case http://cisgw3.law.pace.edu/cases/011031g1.html 6 Aug; Magnus Von Staudingers 
kind of restriction on the inclusion of unfair or unconscionable terms in this manner, although this is often aimed more at consumer contracts than commercial contracts. ${ }^{132}$ Article 13 preserves the provisions of domestic law in this regard. Web traders will therefore have to consider the validity of the technique they use in terms of their own domestic law as well as those of potential business partners. In many cases the applicable law will be the CISG Nothing in this Convention affects the application of any rule of law that may require a party that negotiates some or all of the terms of a contract through the exchange of electronic communications to make available to the other party those electronic communications which contain the contractual terms in a particular manner, or relieves a party from the legal consequences of its failure to do so.

\section{Conclusion}

In the UNECIC UNCITRAL has adopted a text that is aimed at providing legal certainty in international commercial trade where electronic communications are used by the parties. The development of the internet and other modern forms of electronic communications has caused concerns to be raised about the legal certainty and the legal validity of transactions concluded using these methods. Earlier conventions dealing with international trade such as the CISG often do not contain specific provisions dealing with electronic communications, or merely refer to outdated forms of communication such as telegram, simply because these newer electronic methods of communication did not exist at the time of their drafting. Although it is possible to interpret these conventions to apply also to electronic communications, ${ }^{133}$ this was regarded as not ideal.

Kommentar a 14 40-42; Case law: Austria Tantalum powder case http://cisgw3.law.pace.edu/cases/031217a3.html 6 Aug; also Case law: Austria Spacers for insulation glass case http://cisgw3.law.pace.edu/cases/050808a3.html 6 Aug.

132 See for instance the provisions in respect of standard terms in conditions in the German Bürgerliches Gesetzbuch (BGB) (formerly contained in the Allgemeine Geschäftsbedingungen Gesetz 1974) or the English Unfair Contract Terms Act 1977. See generally Magnus Von Staudingers Kommentar a 4 par 24.

133 See for instance Eiselen 1999 EDI Law Review 21-46. 
UNCITRAL first dealt with the legal validity of electronic communications and transactions in the Model Laws it developed in 1996 and 2001. However, these instruments were aimed at providing guidance for the development of domestic law and not international trade law. The UNECIC is specifically aimed at filling that gap. Its provisions were drafted with other conventions such as the CISG specifically in mind and there seems to be a good integration between the provisions of these two instruments. Many of the provisions of the UNECIC draws on the provisions of the very successful CISG and accordingly guidance can be gained from the way in which the CISG has been applied and discussed in case law worldwide as well as various academic commentaries. The Secretariat Commentary provides a further valuable aid for the interpretation of the Convention.

The provisions of the UNECIC on the whole seems to provide clear and sensible solutions which is in accordance with accepted approaches to the legal issues caused by these new technologies worldwide and should go along way to provide the necessary legal certainty aimed at. Whether the UNECIC will emulate the success of its older cousin, the CISG, will only be revealed in time, but there seems to be no apparent obstacles in its way. The fact that to date only 15 countries have signed the Convention and none adopted or ratified it, must not yet be seen as a failure as experience with other UN and UNCITRAL Conventions indicate that these types of conventions usually take between 8 and 15 years for a substantial number of accessions or ratifications to take place. The initial signs however are very positive, also reflected in the large number of states which have made use of the UNCITRAL Model Laws to date. 


\section{Bibliography}

Audit Vienna Sales Convention 154-155

Audit B "The Vienna Sales Convention and the Lex Mercatoria" in

Carbonneau TE (ed) Lex Mercatoria and Arbitration (Transnational Ardsleyon-Hudson 1990)

Bell 2005 Singapore Year Book of International Law 55-73

Bell GF "Why Singapore Should Withdraw Its [Article 95] Reservation to the United Nations Convention on Contracts for the International Sale of Goods (CISG)" 20059 Singapore Year Book of International Law 55-73

Bianca and Bonell Commentary 91

Bianca CM and Bonell MJ Commentary on the International Sales law: The 1980 Vienna Sales Convention (Giuffre Milan 1987)

Cheeseman Business and Online Commerce Law

Cheeseman HR Essentials of Business and Online Commerce Law (2006 Upper Saddle River Pearson)

Christie Law of Contract 76-85

Christie RH The Law of Contract $4^{\text {th }}$ ed (Butterworth Durban 2001)

Connolly 2006 Computer Law \& Security Report

Connolly C "First UN Convention on eCommerce finalised" 2006 Computer Law \& Security Report 31-38

DiMatteo et al International Sales

DiMatteo LA et al International Sales Law: A Critical Analysis of CISG Jurisprudence (Cambridge University Press Cambridge 2005)

Dugard International Law 339

Dugard J International Law - A South African Perspective $2^{\text {nd }}$ ed (Juta Cape Town 2000) 
Eiselen 1999 EDI Law Review 21-46

Eiselen S "Electronic commerce and the UN Convention on Contracts for the International Sale of Goods (CISG) 1980" 1999 EDI Law Review 21-46

Enderlein and Maskow International Sales Law 14-15

Enderlein F and Maskow D International Sales Law: United Nations

Convention on Contracts for the International Sale of Goods (Ocean New York 1992)

Flechtner Pace ILR 295-337

Flechtner H "Comparing the General Good Faith Provisions of the PECL and the UCC: Appearance and Reality" 2001 Pace International Law Review 295-337

Flechtner 1998 Journal of Law and Commerce 187-217

Flechtner H "The Several Texts of the CISG in a Decentralized System: Observations on Translations, Reservations and other Challenges to the Uniformity Principle in Article 7(1)" 1998 Journal of Law and Commerce 187-217

Forsyth Private International Law

Forsyth C Private International Law $4^{\text {th }}$ ed (Juta Cape Town 2003)

Honnold Uniform Words and Uniform Application 143-135

Honnold JO "Uniform Words and Uniform Application. The 1980 Sales

Convention and International Juridical Practice" in Schlechtriem P (ed)

Einheitliches Kaufrecht und Nationales Obligationenrecht (Nomos BadenBaden 1987);

Honnold Uniform Law for International Sales 99-100

Honnold JO, Uniform Law for International Sales under the 1980 United

Nations Convention $3^{\text {rd }}$ ed (Kluwer Deventer 1999) 
Kastely 1988 NW J IntI L \& Bus 594

Kastely AH "Rhetorical Analysis of the Convention" 1988 Northwestern Journal of International Law and Business 574-622

Lookofsky UN Convention on Contracts 18

Lookofsky J "The 1980 United Nations Convention on Contracts for the International Sale of Goods" in Blanpain R (ed) International Encyclopaedia of Law (Kluwer Deventer 1993)

Magnus 1995 RabelsZ 469-494

Magnus U "Die Allgemeinen Grundsätze im UN-Kaufrecht" 1995 RabelsZ 469-494 translated in 1997 International Trade and Business Law Annual 33-56

Magnus Von Staudingers Kommentar

Magnus U Von Staudingers Kommentar zum Bürgerliches Gesetzbuch mit Eimführungsgesetz and Nebengesetze - Wiener UN-Kaufrecht (Sellier Berlin 2005)

Maskow "The Convention" 54

Maskow D "The Convention on the International Sale of Goods from the Perspectives of Socialist Countries" La Vendita Internazionale, Congress at S. Margherita Ligure September 26-28, 1980 (Giuffre Milan 1981)

Rabinowitz 1993 Lex Mundi World Reports 7

Rabinowitz D "Implications of South Africa's Accession to the United Nations Convention on Contracts for the International Sale of Goods" 1993 Lex Mundi World Reports (Supplement)

Raymond 2006 The Computer \& Internet Lawyer 9 Raymond AH "Electronic Commerce and the New UNCITRAL Draft Convention" 2006 The Computer \& Internet Lawyer 9 
Reed and Angel (eds) Computer Law

Reed C and Angel J (eds) Computer Law - The Law and Regulation of Information Technology $6^{\text {th }}$ rev ed (Oxford University Press Oxford 2007)

Schlechtriem 1983 Israel LR 325-326

Schlechtriem P "Recent Developments in International Sales Law" 198318 Israel LR 325-326

Schlechtriem Uniform Sales Law

Schlechtriem P Uniform Sales Law - The UN-Convention on Contracts for the International Sale of Goods (Manz Vienna 1986)

Schlechtriem and Schwenzer (eds) Commentary

Schlechtriem P and Schwenzer I (eds) Commentary on the UN Convention on the International Sale of Goods (CISG) $2^{\text {nd }}$ ed (Oxford University Press Oxford 2005)

Van der Merwe et al Contract General Principles 66 Van der Merwe SWJ et al Contract General Principles $2^{\text {nd }}$ ed (Juta Cape Town 2003)

Vogel, Shannon and Doernberg Income Tax Treaties 30 Vogel K, Shannon H and Doernberg R United States Income Tax Treaties Part I (Kluwer Deventer 1989)

Wang and Andersen 2004 Vindobona JICL \& A 148

Wang $X$ and Andersen $C B$ "The Chinese Declaration against Oral Contracts under the CISG" 2004 Vindobona Journal of International Commercial Law \& Arbitration 148-164

\section{Register of Legislation}

\section{South African:}

Electronic Communications and Transactions Act 25 of 2002 


\section{Foreign:}

\section{Canada}

Uniform Electronic Commerce Act 1999

\section{United Kingdom}

Unfair Contract Terms Act 1977

\section{German}

Bürgerliches Gesetzbuch (BGB) Allgemeine Geschäftsbedingungen Gesetz 1974

\section{Register of Case Law}

\section{South African:}

Cape Explosive Works Ltd v SA Oil and Fat Industries (Ltd) 1921 CPD 244

Crawley v R 1909 TS 1105

Jamieson v Sabingo 2002 (4) SA 49 (SCA)

Kergeulen Sealing and Whaling Co Ltd v CIR 1939 AD 487

Sonap Petroleum SA (Pty) Ltd v Papadogianis 19923 SA 234

\section{Foreign:}

\section{Austria}

Pork case 7 March 2002 Oberlandesgericht [Appellate Court] Graz [Found on internet] http://cisgw3.law.pace.edu/cases/020307a3.html [Date of use 8 August 2007]

Spacers for insulation glass case 8 August 2005 Oberlandesgericht [Appellate Court] Linz [Found on internet] http://cisgw3.law.pace.edu/cases/050808a3.html [Date of use 8 August 2007]

Tantalum powder case 17 December 2003 Oberster Gerichtshof [Supreme Court] [Found on internet] http://cisgw3.law.pace.edu/cases/031217a3.html [Date of use 8 August 2007]

\section{Belgium}

NV A.R. v. NV I 15 May 2002 Hof van Beroep [Appellate Court] Gent [Found on internet] http://cisgw3.law.pace.edu/cases/020515b1.html [Date of use 8 August 2007] 


\section{Germany}

Circuit boards case 5 October 1998 Oberlandesgericht [Appellate Court] Hamburg http://cisgw3.law.pace.edu/cases/981005g1.html [Date of use 6 August 2007]

Frozen pork case 2 March 2005 Bundesgerichtshof [Federal Supreme Court]

[Found on internet] http://cisgw3.law.pace.edu/cases/050302g1.html

[Date of use 6 August 2007]

Machinery case 31 October 2001 Bundesgerichtshof [Supreme Court] [Found on internet] http://cisgw3.law.pace.edu/cases/011031g1.html [Date of use 6 August 2007]

\section{Hungary}

Mushrooms case 17 November 1995 Budapest Arbitration proceeding Vb 94124 http://cisgw3.law.pace.edu/cases/951117h1.html [Date of use 6 August 2007]

Italy

Agricultural products case (Padova) 25 February 2004 Tribunale [District Court] http://cisgw3.law.pace.edu/cases/040225i3.html [Date of use 8 August 2007]

\section{Netherlands}

Rynpoort Trading v. Meneba Meel 23 April 2003 Gerechtshof [Appellate Court] Gravenhage [Found on internet] http://cisgw3.law.pace.edu/cases/030423n1.html [Date of use 8 August 2007]

\section{Spain}

Motors case 22 September 2003 Audiencia Provincial [Appellate Court] Navarra [Found on internet] http://cisgw3.law.pace.edu/cases/030922s4.html [Date of use 8 August 2007]

\section{Register of UNCITRAL Documentation}

UNCITRAL 1996 Guide to Enactment

UNCITRAL 1996 Model Law on Electronic Commerce with Guide to 
Enactment [Found on internet]

http://www.uncitral.org/uncitral/en/uncitral texts/electronic commerce/1996

Model.html [Date of use 8 August 2007]

UNCITRAL 2004 Agenda of the Working Group for the $44^{\text {th }}$ Session in

A/CN.9/WG.IV/WP.109 [Found on internet]

http://daccessdds.un.org/doc/UNDOC/LTD/V04/562/31/PDF/V0456231.pdf

?OpenElement [Date of use 6 August 2007]

UNCITRAL A/CN.9/WG.IV/WP.94 (14 February 2002)

UNCITRAL Documentation http://www.uncitral.org/ 8 Aug

UNCITRAL Documentation [Found on internet]

http://www.uncitral.org/uncitral/en/uncitral_texts/electronic_commerce/2005

Convention.html [Date of use 8 August 2007]

UNCITRAL G.A.Res.51/162 (16 December 1996)

UN Doc.A/RES/51/162 (30 January 1997)

UNCITRAL Model Law on Electronic Signature (1991)

UNCITRAL Report of the Working Group on Electronic Commerce on the Work of its $38^{\text {th }}$ Session (New York 12-23 March 2001) A/CN.9/484 (24 April 2001)

UNCITRAL Secretariat Explanatory Note http://www.uncitral.org/ 8 Aug UNCITRAL Secretariat Explanatory Note [Found on internet] http://www.uncitral.org/pdf/english/texts/electcom/06-57452_Ebook.pdf [Date of use 8 August 2007]

UNCITRAL Working Group on Electronic Commerce Report on the work of its forty-fourth session (Vienna, 11-22 October 2004) A/CN.9/571 
UNCITRAL Working Group on Electronic Commerce Report on the Work of its $38^{\text {th }}$ Session (New York 12-23 March 2001) A/CN.9/484 (24 April 2001)

UNICITRAL Working Group Report 5-9 May 2003 A/CN.9/528 (19 May 2003)

\section{Register of International Conventions}

Convention on the Limitation Period in the International Sale of Goods, 1974 Convention on the Recognition and Enforcement of Foreign Arbitral Awards, 1958

Protocol to Convention on the Limitation Period in the International Sale of Goods, 1980

UN Convention on Contracts for the International Sale of Goods, 1980

UN Convention on Independent Guarantees and Stand-by Letters of Credit, 1995

UN Convention on the Assignment of Receivables in International Trade, 2001

UN Convention on the Liability of Operators of Transport Terminals in International Trade, 1991

UN Convention on the Use of Electronic Communications in International Contracts, 2005

Vienna Convention on the Law of Treaties, 1969

\section{Register of internet resources}

Andersen 1998 Pace ILR 403-410 http://www.cisg.law.pace.edu/ 8 Aug Andersen CB "Furthering the Uniform Application of the CISG: Sources of Law on the Internet" 1998 Pace International Law Review 403-410 [Found on internet] http://www.cisg.law.pace.edu/cisg/biblio/andersen1.html [Date of use 8 August 2007]

DoC 2000 Green Paper on eCommerce http://www.polity.org.za/ 19 Nov Department of Communications 2000 Green Paper on Electronic Commerce for South Africa [Found on internet] http://www.polity.org.za/polity/govdocs/green_papers/greenpaper/index.html [Date of use 19 November 2007] 
Farnsworth TLDB http://tldb.uni-koeln.de/ 8 Aug

Farnsworth EA "Duties of Good Faith and Fair Dealing under the

UNIDROIT Principles, Relevant International Conventions, and National

Laws" Transnational Law Digest \& Bibliography 47-63 [Found on internet]

http://tldb.uni-koeln.de/php/pub_show_document.php?pubdocid=122100

[Date of use 8 August 2007]

Ferrari 1994 Georgia JICL 183-228 http://www.cisg.law.pace.edu/ 8 Aug Ferrari F "Uniform Interpretation of the 1980 Uniform Sales Law" 1994 Georgia Journal of International and Comparative Law 183-228 [Found on internet] http://www.cisg.law.pace.edu/cisg/biblio/franco.html [Date of use 8 August 2007]

Ferrari 1999 Journal of Law and Commerce 245-261

http://www.cisg.law.pace.edu/ 8 Aug

Ferrari F "CISG Case Law: A New Challenge for Interpreters" 1999 Journal of Law and Commerce 245-261 [Found on internet] http://www.cisg.law.pace.edu/cisg/biblio/ferrari3.html [Date of use 8 August 2007]

Rosett 1984 Ohio State LJ 265-305 http://www.cisg.law.pace.edu/ 8 Aug Rosett A "Critical Reflections on the United Nations Convention on Contracts for the International Sale of Goods" 198445 Ohio State Law Journal 265-305 [Found on internet] http://www.cisg.law.pace.edu/cisg/biblio/bib2.html [Date of use 8 August 2007]

Stephan 1999 http://ssrn.com/abstract=169209 8 Aug Stephan PB "The Futility of Unification and Harmonization in International Commercial Law" 1999 University of Virginia School of Law, Legal Studies Working Paper No 99-10 [Found on internet] http://ssrn.com/abstract=169209 [Date of use 8 August 2007] 
Van Alstine 1998 Univ Pennsylvania LR 687-793 http://www.cisg.law.pace.edu/ 8 Aug

Van Alstine MP "Dynamic Treaty Interpretation" 1998 University of

Pennsylvania Law Review 687-793 [Found on internet]

http://www.cisg.law.pace.edu/cisg/biblio/alstine2.html [Date of use 8 August 2007]

\section{List of abbreviations}

$\begin{array}{ll}\text { a } & \text { article } \\ \text { ch } & \text { chapter(s) } \\ \text { CISG } & \text { Convention for the International Sale of Goods } \\ \text { cl } & \text { clause(s) } \\ \text { DoC } & \text { Department of Communications } \\ \text { ECT } & \text { Electronic Communications and Transactions } \\ \text { par } & \text { paragraph(s) } \\ \text { S } & \text { section(s) } \\ \text { sch } & \text { schedule(s) } \\ \text { UNCITRAL } & \text { United Nations Commission on International Trade Law } \\ \text { UNECIC } & \text { United Nations Convention on the Use of Electronic } \\ & \text { Communications } \\ \text { UN/CEFACT } & \text { United Nations Centre for Trade Facilitation and Electronic } \\ & \text { Business }\end{array}$

